\title{
PENGELOLAAN PERIKANAN DEMERSAL DI LAUT ARAFURA: PENDEKATAN BIOEKONOMI
}

\author{
Management of Demersal Fishery in the Arafura Sea: \\ A Bio-Economic Approach
}

\author{
*Yesi Dewita Sari', Yusman Syaukat', Tridoyo Kusumastanto² dan Sri Hartoyo ${ }^{2}$ \\ ${ }^{1}$ Balai Besar Riset Sosial Ekonomi Kelautan dan Perikanan \\ Gedung Balitbang KP I Lt. 4 \\ Jalan Pasir Putih Nomor 1 Ancol Timur, Jakarta Utara, Indonesia \\ Telp: (021) 64711583 Fax: 64700924 \\ ${ }^{2}$ Institut Pertanian Bogor \\ JI. Raya Dramaga, Kampus IPB Dramaga Bogor,16680 West Java, Indonesia \\ Diterima tanggal: 18 April 2018 Diterima setelah perbaikan: 21 Mei 2018 \\ Disetujui terbit: 18 Juni 2018 \\ "email: yesidewita@gmail.com
}

\begin{abstract}
ABSTRAK
Laut Arafura merupakan salah satu perairan yang penting, sebesar $21 \%$ potensi ikan Indonesia terdapat di perairan Arafura yaitu 2,64 juta ton per tahun. Pemanfaatan sumber daya ikan demersal terutama udang di Laut Arafura telah dilakukan semenjak tahun 1970an oleh perusahaan dengan sistem joint venture. Penelitian ini bertujuan untuk mengetahui tingkat optimal pengelolaan sumber daya ikan demersal di Laut Arafura dan perubahan rente ekonomi setelah adanya kebijakan moratorium kapal asing di Indonesia yaitu pelarangan penggunaan kapal pukat dan kapal asing. Penelitian ini menggunakan data sekunder runtun waktu yang bersumber dari Kementerian Kelautan dan Perikanan, Badan Pusat Statistik serta hasil-hasil penelitian yang relevan. Metode analisis data menggunakan model bioekonomi perikanan dengan model surplus produksi Walters dan Hilborn. Analisis kebijakan ekonomi meliputi jumlah alat tangkap, jumlah investasi dan rente ekonomi maksimum. Jumlah produksi tertinggi terjadi ketika pengelolaan pada kondisi maksimum secara biologi; sedangkan jumlah alat tangkap tertinggi yang diperbolehkan ketika pengelolaan pada kondisi open akses menggunakan alat tangkap pancing rawai dasar, serta rente ekonomi tertinggi diperoleh ketika pengelolaan pada kondisi maksimum secara ekonomi menggunakan pancing rawai dasar. Kebijakan pemerintah terkait moratorium kapal perikanan asing, memberikan kesempatan lebih banyak untuk kapal perikanan Indonesia dalam melakukan penangkapan ikan demersal di WPP 718. Jumlah kapal perikanan dengan menggunakan alat tangkap pancing rawai dasar dapat dikembangkan sampai 4 ribuan unit untuk memanfaatkan ikan demersal yang optimal secara ekonomi, sehingga rente ekonomi maksimum dapat diperoleh sebesar 3,40 trilyun rupiah per tahun.
\end{abstract}

Kata Kunci: perikanan demersal; bioekonomi; Walters dan Hilborn; Laut Arafura

\begin{abstract}
Arafura sea is one of important fishing ground in Indonesia, contributing $21 \%$ of fisheries at about 2,64 million ton/year. Arafura's demersal fishery has been exploited since 1970 by joint venture system. This study aims to determine the optimum level of demersal fish management in Arafura Sea as well as the fluctuations of economic rent after the foreign fishing vessel moratorium in Indonesia. The study collected time series data from 2001-2014 from Ministry of Marine and Fisheries, Statistics Indonesia and relevant researches. The data were analyzed using bioeconomic model, particularly Walters and Hilborn Model. Analysis of economic policy includes fishing gears, investments and maximum economic rents. The results show that the maximum production occurs when fisheries management is on maximum yield. The highest number of permitted fishing gear is reached when the management is on open access condition using the set longline, while the maximum economic rents are obtained when the management is on maximum economic yield using the set long line. Foreign fishing vessel moratorium gives more opportunity to Indonesian vessels to catch more demersal fish in WPP 718. The number of total optimum fishing vessel could be increased up to 4 thousand units in WPP 718 for demersal fishery in order reach optimum economic rent of 3.40 trillion rupiah per year.
\end{abstract}

Keywords: demersal fishery; bioeconomic; Walters and Hilborn; Arafura Sea 


\section{PENDAHULUAN}

Laut Arafura merupakan salah satu perairan yang penting dan telah memberikan kontribusi besar dalam pembangunan perikanan nasional. Potensi yang tinggi berupa ikan-ikan bernilai ekonomis tinggi seperti udang dan ikan demersal, sehingga perairan Arafura dikenal sebagai the golden fishing ground. Usaha penangkapan ikan di perairan Arafura sudah berkembang pesat dan diusahakan secara komersial, terutama untuk wilayah perairan di atas 12 mil dari garis pantai dan di wilayah ZEE Indonesia di bagian selatan perairan. Alat tangkap dominan yang digunakan di bagian selatan adalah pukat udang dan pukat ikan. Di wilayah perairan Papua dan sekitarnya, khususnya untuk wilayah kurang dari 12 mil ke arah pantai, penangkapan ikan dilakukan menggunakan alat tangkap antara lain: trammel net, bagan perahu, pancing ulur, bubu, huhate, tuna long line, mini purse seine dan gillnet.

Berdasarkan data perizinan usaha penangkapan ikan yang dikeluarkan Direktorat Jenderal Perikanan Tangkap (Mulyana, 2012), usaha penangkapan ikan di Laut Arafura oleh kapal-kapal perikanan berukuran di atas 30 GT umumnya menggunakan alat tangkap: pukat ikan, pukat udang, jaring insang hanyut oseanik, rawai dasar, pancing cumi, dan jaring insang hanyut pantai. Total kapal perikanan di atas $30 \mathrm{GT}$ yang beroperasi sebanyak 980 unit atau jumlah GT sebanyak 184.024 dengan dominan alat tangkap pukat. Hasil tangkapan utama kapal pukat adalah udang dan hasil tangkapan sampingan kapal pukat yaitu ikan demersal. Kapal pukat yang beroperasi di Laut Arafura telah berkembang semenjak tahun 1970an, dimulai dengan perusahaan joint venture yang berpangkalan di beberapa pelabuhan seperti Sorong, Ambon, Tual, Merauke, Kendari dan Makassar.

Secara ekonomi, keberadaan kapal-kapal dan industri perikanan tangkap terpadu telah memberikan sumbangan yang cukup berarti dalam bentuk Penerimaan Negara Bukan Pajak (PNBP), penyerapan tenaga kerja, dan pembangunan ekonomi regional. Namun, Wilayah pengelolaan perairan Arafura ini merupakan perairan rawan terjadinya praktek IUU fishing yang dilakukan oleh kapal-kapal perikanan baik yang memiliki izin penangkapan maupun tidak. Nikijuluw (2008) menyebutkan bahwa di Perairan Arafura beroperasi sekitar 3.000 kapal secara ilegal.
Semenjak akhir tahun 2014, pemerintah Indonesia menetapkan kebijakan pelarangan bagi kapal asing untuk melakukan penangkapan ikan di perairan Indonesia (PermenKP no 56 tahun 2014) dan larangan penggunaan alat tangkap pukat hela dan pukat tarik (PermenKP no 2 tahun 2015), maka seluruh kapal pukat udang dan pukat ikan sudah tidak beroperasi di WPP 718. Dengan demikian, struktur armada penangkapan ikan mengalami perubahan, kapal perikanan yang beroperasi hanya kapal perikanan Indonesia dengan kapasitas penangkapan yang jauh lebih kecil dibandingkan kapasitas kapal pukat. Kebijakan ini merupakan kebijakan limited entry yang telah banyak diterapkan pada perikanan di negara-negara subtropis.

Kebijakan limited entry pertamakali diterapkan oleh Australia, British Columbia, Alaska dan negara bagian Washington pada akhir tahun 1960an dan awal tahun 1970an. Selanjutnya diikuti oleh Amerika Serikat, Kanada dan beberapa perairan Eropa (Grainger \& Parker, 2013). Alaska dan Kanada menerapkan limited entry untuk perikanan salmon, California, Oregon dan Washington untuk perikanan kepiting, perancis untuk perikanan kerang dan Selandia Baru untuk perikanan lobster.

Kebijakan limited entry dapat meningkatkan rente ekonomi (Anderson (1985), Campbell \& Lindner (1990) dan Asano et al. (2016)). Anderson (1985) menunjukkan bahwa kebijakan limited entry dapat meningkatkan rente ekonomi perikanan ketika penggunaan kapal perikanan pada unit biaya yang mengalami peningkatan serta adanya peningkatan penggunaan input yang tidak dibatasi. Penelitian selanjutnya dilakukan Campbell dan Lindner (1990) terhadap perubahan kesejahteraan apabila nelayan atau perusahaan perikanan dapat menggantikan penggunaan input yang dibatasi dengan input yang tidak dibatasi. Dalam hal ini, input yang dibatasi adalah jumlah kapal sedangkan input yang tidak dibatasi adalah biaya operasional. Hasil penelitian Asano et al. (2016) menunjukkan bahwa kebijakan limited entry tidak menyebabkan penggunaan kapital yang berlebihan atau jumlah hari melaut berlebihan serta tidak ada insentif untuk penambahan investasi kapal. Perikanan dengan pemanfaatan pada tingkat MSY, kebijakan limited entry dapat meningkatkan jumlah hasil tangkapan, jumlah biomass dan rente ekonomi. Penelitian ini bertujuan untuk mengetahui perubahan rente ekonomi perikanan setelah adanya kebijakan moratorium kapal asing pada rezim pengelolaan open akses, optimal secara biologi (MSY) dan 
optimal secara ekonomi (MEY), sehingga dapat dirumuskan kebijakan yang tepat untuk perikanan demersal di WPP 718.

\section{METODOLOGI}

\section{Metode, Lokasi dan Waktu Penelitian}

Metode penelitian yang digunakan dalam penelitian ini adalah metode studi kasus, dengan satuan kasus perikanan tangkap khususnya ikan demersal di Wilayah Pengelolaan Perikanan (WPP) 718. Penelitian ini dilakukan di WPP 718 yang meliputi wilayah administrasi Papua, Papua Barat dan sebagian Maluku. Penelitian berlangsung pada tahun 2017 meliputi tahap persiapan, pengumpulan data sekunder, pengolahan data, penyusunan model dan verifikasi dari model yang dihasilkan. Kebijakan ekonomi yang dikaji dalam penelitian ini adalah jumlah alat tangkap yang terkait dengan jumlah investasi dan rente ekonomi dari pemanfaatan sumber daya ikan demersal di Laut Arafura.

\section{Jenis, Sumber dan Teknik Pengumpulan Data}

Data yang dikumpulkan pada penelitian ini adalah data sekunder. Data sekunder bersumber dari Buku Statistik Kelautan dan Perikanan, Badan Pusat Statistik, laporan hasil penelitian, jurnal terpublikasi dan sumber lainnya yang dapat dipercaya. Jenis data sekunder yang digunakan adalah data runtun waktu mulai tahun 2001 sampai tahun 2014 untuk jumlah hasil tangkapan, jumlah alat tangkap, harga ikan dan indeks harga konsumen. Data jumlah hasil tangkapan menggunakan data produksi seluruh ikan demersal di WPP 718. Data harga ikan yang digunakan adalah harga ikan bawal hitam dan bawal putih, kakap merah dan kakap putih, manyung, kuwe, kuro dan semua jenis udang. Data jumlah perijinan kapal perikanan yang melakukan penangkapan ikan di WPP 718 tahun 2011 dan 2017 juga digunakan dalam penelitian ini serta data lainnya.

\section{Metode Analisis Data}

Metode analisis data menggunakan model Walters \& Hilborn. Model tersebut dipilih setelah dilakukan beberapa uji model, dan diperoleh bahwa Model Walters \& Hilborn merupakan model terbaik untuk menggambarkan data yang dimiliki. Model Surplus produksi yang dikembangkan oleh Walters \& Hilborn (1976) dikenal sebagai difference model. Model Walters dan Hilborn juga dikenal sebagai model yang berbeda dari model Schaefer,

$$
x_{t+1}=x_{t}+r x_{t}\left(1-\frac{x_{t}}{K}\right)-h_{t}
$$

$x_{t+1}=$ Biomasa pada waktu $\mathrm{t}+1 /$ Biomass at $t+1$ time

$x_{t}=$ Biomasa pada waktu $\mathrm{t} /$ Biomass at $t$ time

$r \quad=$ Tingkat pertumbuhan intrinsik/ Intrinsic growth rate

$K=$ Daya dukung perairan/ Carrying capacity

$h_{t}=$ Jumlah hasil tangkapan pada waktu $\mathrm{t} /$ Harvest at t time

Model Walters \& Hilborn menggunakan versi model biologi diskrit, sedangkan model Schaefer tidak diskrit. Estimasi parameter biologi dengan metode regresi linier berganda, yang relatif lebih mudah karena dapat dilakukan secara langsung dari persamaan yang dimiliki (Hilborn and Walters, 1992). Prosedur estimasi parameter biologi dengan menggunakan Walters dan Hilborn adalah:

$$
x_{t}=\frac{U_{t}}{q}
$$

Dimana: $U_{t}=\frac{h_{t}}{E_{t}}, \quad=$ hasil tangkapan per unit upaya penangkapan/catch per unit effort (CPUE) $q=$ koefisien kemampuan tangkap/ catchability coefficient

Dengan melakukan substitusi persamaan 2 ke persamaan 1, maka dapat dituliskan:

$$
\frac{U_{t+1}}{q}=\frac{U_{t}}{q}+\frac{r U_{t}}{q}\left(1-\frac{U_{t}}{K q}\right)-U_{t} E_{t}
$$

Dengan memindahkan $\frac{U_{t}}{q}$ ke sebelah kiri, dan mengalikan kedua sisi dengan $q / U_{t}$ maka diperoleh persamaan berikut:

$$
\frac{U_{t+1}}{U_{t}}-1=r-\frac{r}{K q} U_{t}-q E_{t}
$$

Persamaan (4) dapat diselesaikan dengan model regresi linier berganda yang terdiri dari variabel bebas (independent) CPUE $\left(U_{t}\right)$ dan jumlah alat tangkap $(E)$ dan variabel terikat (dependent) adalah tingkat perubahan biomasa ikan. Persamaan (4) menunjukkan bahwa model surplus produksi Walters dan Hilborn adalah linier, lag dan reciprocal. Secara umum, bentuk persamaan regresi linier berganda adalah:

$$
Y_{t}=\beta_{0}-\beta_{1} X_{1 t}-\beta_{2} X_{2 t}+\varepsilon_{t}
$$


Dimana/Where:

$$
\begin{array}{ll}
Y_{t}=\frac{U_{t+1}}{U_{t}}-1= & \begin{array}{l}
\text { Perbandingan } C P U E_{t+} \text { dengan } \\
\text { CPUE } / \text { Comparison of } C P U E_{t+1} \\
\text { with CPUE }
\end{array} \\
X_{1 t}=U_{t} & =\begin{array}{l}
C P U E \text { pada waktu } t / C P U E \text { at } \\
\text { time } t
\end{array} \\
X_{2 t}=E_{t} & =\begin{array}{l}
\text { Jumlah alat tangkap/ Number of } \\
\text { fishing gear }
\end{array} \\
\varepsilon_{t}=\text { error }- \text { term } &
\end{array}
$$

Menggunakan persamaan 5, sehingga dapat diperoleh masing-masing koefisien. Koefisien tersebut dapat digunakan untuk melakukan estimasi parameter biologi $r, \mathrm{~K}$ dan $\mathrm{q}$ secara terpisah dari ketiga koefisien yang dihasilkan. Pendugaan nilai biomassa, hasil tangkapan dan alat tangkap untuk masing-masing pilihan pengelolaan diturunkan dari model bioekonomi Gordon Schaefer (Tabel 1).

\section{HASIL DAN PEMBAHASAN}

\section{Karakteristik Perikanan Demersal di Laut Arafura}

Laut Arafura atau laut Arafuru adalah laut yang terletak di antara wilayah Australia dan Pulau Papua, tepatnya di sebelah selatan kepulauan Aru dan berada di wilayah samudera Pasifik. Kendati berada di dekat pulau Papua, wilayah laut Arafura terletak di provinsi Maluku bagian tenggara dan berbatasan dengan pantai Irian Jaya di sebelah barat daya. Laut Arafura memiliki luas wilayah yang mencapai $650.000 \mathrm{~km}^{2}$ dengan kedalaman laut maksimal kurang lebih sekitar 3,68 km dan merupakan laut transgresi di dangkalan Sahul. Laut Arafura merupakan laut yang termasuk dalam zona Neritik. Laut Arafura berbatasan dengan beberapa laut di sebelah barat, yaitu berbatasan dengan laut Banda atau kepulauan Maluku dan laut Timur. Laut Arafura berbatasan dengan kepulauan Aru di sebelah utara dan pulau Papua di sebelah timur. Selain itu, laut Arafura juga berbatasan dengan wilayah Australia di sebelah selatan. Di sekitar wilayah laut Arafura terdapat beberapa pulau, yaitu pulau Aru, pulau Kai, dan pulau Tanimbar.

Laut Arafura merupakan wilayah perairan yang menyimpan sumber daya alam perikanan yang sangat potensial. Laut Arafura menyimpan banyak jenis ikan dan udang, maka tidak heran beberapa perusahaan memiliki pangkalan laut di Sorong dan Ambon guna menangkap ikan-ikan yang berada di wilayah perairan Laut Arafura. Setidaknya terdapat sekitar 228 spesies hewan laut yang ada di kawasan laut Arafura yang mewakili 101 family yang tergolong dalam 10

\begin{tabular}{|c|c|c|c|}
\hline \multirow[b]{2}{*}{$\begin{array}{l}\text { Kriteria/ } \\
\text { Criterion }\end{array}$} & \multicolumn{3}{|c|}{ Pilihan Pengelolaan/Management Alternative } \\
\hline & $\begin{array}{l}\text { Open Akses/ } \\
\text { Open Access }\end{array}$ & $\begin{array}{c}\text { Maksimum Secara } \\
\text { Biologi/ Maximum } \\
\text { Sustainable Yield } \\
\text { (MSY) }\end{array}$ & $\begin{array}{c}\text { Maksimum Secara } \\
\text { Ekonomi/ Maximum } \\
\text { Economic Yield (MEY) }\end{array}$ \\
\hline $\begin{array}{l}\text { Jumlah alat } \\
\text { tangkap/Effort }\end{array}$ & $E_{O A}=\frac{r}{q}\left(1-\frac{c}{p \cdot q \cdot K}\right)$ & $E_{M S Y}=\frac{r}{2 \cdot q}$ & $E^{*}=\frac{r}{2 q}\left(1-\frac{c}{p q K}\right)$ \\
\hline $\begin{array}{l}\text { Hasil tangkapan/ } \\
\text { Harvest }\end{array}$ & $h_{O A}=\left(\frac{r \cdot c}{p \cdot q}\right)\left(1-\frac{c}{p \cdot q \cdot K}\right)$ & $h_{M S Y}=\frac{r \cdot K}{4}$ & $h^{*}=\frac{K}{4}\left(1+\frac{c}{p q K}\right)\left(1-\frac{c}{p q K}\right)$ \\
\hline Stok/Biomass & $x_{O A}=\frac{c}{p \cdot q}$ & $x_{M S Y}=\frac{r}{2 \cdot q}$ & $x^{*}=\frac{h}{q \cdot E}$ \\
\hline Rente/Rent & $\pi=p \cdot h_{O A}-c \cdot E_{O A}$ & $\pi=p \cdot h_{M S Y}-c \cdot E_{M S Y}$ & $\pi=p \cdot\left(q K E\left(1-\frac{q}{r} E\right)\right)-c E$ \\
\hline
\end{tabular}
kelompok sumber daya, hal ini didasarkan pada hasil riset yang dilakukan oleh Balai Riset Perikanan Laut tahun 2006. Kelompok ikan demersal merupakan hasil tangkapan paling tinggi

Tabel 1. Persamaan Untuk Pendugaan Nilai Biomassa, Hasil Tangkapan dan Alat Tangkap. Table 1. Formulation For Estimated Value of Biomass, Harvest and Fishing Gear.

Sumber: Clark, 1990/Source: Clark, 1990 
yaitu $58,89 \%$, kemudian disusul ikan pelagis $11,36 \%$, kepiting $9,88 \%$, udang $7,80 \%$ dan kelompok lainnya kurang dari 4\% (Wedjatmiko, 2008).

Kelompok ikan demersal yang tertangkap terdiri dari 135 spesies yang tergolong dalam 61 famili. Hasil tangkapan tersebut didominasi famili ikan petek yang mencapai $19,57 \%$ dan famili ikan tiga waja sekitar $11,41 \%$. Hasil tangkapan kelompok kurtase terdiri dari udang dan kepiting. Jenis udang yang tertangkap sebanyak 19 spesies yang mewakili 7 famili dan hasil tangkapan tertinggi adalah famili udang peneidae sebesar $86,23 \%$. Pada kelompok kepiting, tertangkap sebanyak 11 spesies (Pusat Penelitian dan Pengembangan Sumber daya Laut dan Pesisir, 2013).

Berdasarkan Keputusan Menteri Kelautan No 50 tahun 2017 tentang estimasi potensi, jumlah tangkapan yang diperbolehkan, dan tingkat pemanfaatan sumber daya ikan di wilayah pengelolaan perikanan Negara Republik Indonesia, total potensi ikan di WPP 718 adalah 2,64 juta ton. Potensi terbesar adalah ikan demersal yaitu 876.722 ton dan potensi udang 62.842 ton. Tingkat pemanfaatan tertinggi adalah kelompok cumi dan ikan karang yaitu 1,28 dan 1,07 yang berarti bahwa jumlah hasil tangkapan ikan telah melebihi dari jumlah tangkapan yang diperbolehkan. Tingkat pemanfaatan terendah adalah jenis ikan pelagis kecil yaitu $0,51 \%$. Jenis kelompok ikan yang telah mengalami tangkap lebih adalah cumi-cumi, ikan karang, ikan pelagis besar dan lobster. Secara lebih rinci besarnya potensi, jumlah tangkapan yang diperbolehkan dan tingkat pemanfaatan untuk perikanan di Laut Arafura disajikan pada Tabel 2.

Rata-rata tingkat pemanfaatan dari seluruh jenis kelompokikan adalah 0,89 dengan standarerror 0,0755 . Jenis kelompok ikan yang telah mengalami tangkap lebih dan yang mendekati tangkap lebih adalah jenis kelomok ikan cumi-cumi, ikan karang, ikan pelagis besar dan lobster. Sedangkan jenis kelompok ikan dengan tingkat pemanfaatan masih rendah, atau harus dikembangkan untuk mengoptimalkan pemanfaatan adalah ikan pelagis kecil, ikan demersal dan rajungan.

Semenjak diberlakukan Permen 56 tahun 2014 tentang moratorium perpanjangan dan pemberian ijin baru kapal perikanan asing dan Permen No 2 tahun 2015 tentang pelarangan trawl di seluruh perairan Indonesia, maka struktur armada penangkapan yang beroperasi di perairan Arafura mengalami perubahan. Kapal perikanan yang mendapat izin dari pemerintah pusat (berukuran lebih dari 30 GT) telah beroperasi sebanyak 1551 unit yang terdiri dari armada dengan alat tangkap jaring insang oseanik, pancing cumi, purse seine, pancing rawai dasar, bouke ami, jaring insang liong bun dan pancing ulur (Tabel 3).

Tabel 2. Potensi, Jumlah Tangkapan yang Diperbolehkan dan Tingkat Pemanfaatan Ikan di WPP 718, Tahun 2017.

Table 2. Potential, Total Allowable Catch and Utilization Level Fish in Fisheries Management Area 718, 2017.

\begin{tabular}{clrrc}
\hline No & \multicolumn{1}{c}{$\begin{array}{c}\text { Jenis Kelompok Ikan/ } \\
\text { Type of Fish Group }\end{array}$} & $\begin{array}{c}\text { Potensi/ } \\
\text { Potential }\end{array}$ & \multicolumn{1}{c}{$\begin{array}{c}\text { JTB/ } \\
\text { TAC }\end{array}$} & $\begin{array}{c}\text { Tingkat Pemanfaatan/ } \\
\text { Utilization Level }\end{array}$ \\
\hline 1 & Ikan pelagis kecil/Small pelagic & 836,973 & 669,578 & 0.51 \\
2 & Ikan pelagis besar/Big pelagic & 818,870 & 655,096 & 0.99 \\
3 & Ikan demersal/Demersal & 876,722 & 701,378 & 0.67 \\
4 & Ikan karang/Coral fish & 29,485 & 23,588 & 1.07 \\
5 & Udang penaeid/Crustaceans & 62,842 & 50,274 & 0.86 \\
6 & Lobster/Lobster & 1,187 & 950 & 0.97 \\
7 & Kepiting/Mangrove mud crab & 1,498 & 1,198 & 0.85 \\
8 & Rajungan/Swimming crab & 775 & 620 & 0.77 \\
9 & Cumi-cumi/Common squids & 9,212 & 7,370 & 1.28 \\
\hline \multirow{2}{*}{ Jumlah/Total/Rata-ratal/Average } & $\mathbf{2 , 6 3 7 , 5 6 4}$ & $\mathbf{2 , 1 1 0 , 0 5 1}$ & $\mathbf{0 . 8 9}$ \\
\hline
\end{tabular}

Sumber: Kementerian Kelautan dan Perikanan Republik Indonesia (2017)/

Source: Ministry of Marine Affairs and Fisheries Republic of Indonesia (2017) 
Tabel 3. Jumlah Kapal Perikanan (> 30 GT) Berdasarkan Jenis Alat Tangkap yang Beroperasi di Laut Arafura, 2017.

Tabel 3. Number of Fishing Vessel (> 30 GT) Based on Type of Fishing Gear in Arafura Sea, 2017.

\begin{tabular}{|c|c|c|c|c|c|}
\hline No & $\begin{array}{l}\text { Nama Alat Tangkap/ } \\
\text { Fishing Gear Name }\end{array}$ & $\begin{array}{l}\text { Jumlah/ } \\
\text { Number (unit) }\end{array}$ & $\begin{array}{c}\text { Prosentase/ } \\
\text { Percentage }\end{array}$ & $\begin{array}{l}\text { Rata-rata GT/ } \\
\text { Average GT }\end{array}$ & $\begin{array}{l}\text { Produktivitas/ } \\
\text { Productivity }\end{array}$ \\
\hline 1 & $\begin{array}{l}\text { Pancing rawai dasar/ } \\
\text { Set long lines }\end{array}$ & 134 & 8.64 & 75 & 1.00 \\
\hline 2 & $\begin{array}{l}\text { Jaring insang oseanik/ } \\
\text { Oceanic gillnet }\end{array}$ & 511 & 32.95 & 97 & 0.85 \\
\hline 3 & Pancing cumi/Squid jigging & 589 & 37.98 & 106 & 0.75 \\
\hline 4 & Jaring lingkar/Purse seine & 256 & 16.51 & 140 & 1.30 \\
\hline 5 & Bouke ami/Bouke ami & 12 & 0.77 & 86 & 0.85 \\
\hline 6 & $\begin{array}{l}\text { Jaring insang liong bun/ Lion } \\
\text { bun gillnet }\end{array}$ & 39 & 2.51 & 59 & 0.65 \\
\hline 7 & Pancing ulur/ Handline & 10 & 0.64 & 81 & 0.60 \\
\hline \multicolumn{2}{|c|}{ Jumlah/ Total/ Rata-rata//Average } & 1,551 & 100.00 & 92 & 0.86 \\
\hline
\end{tabular}

Sumber: Kementerian Kelautan dan Perikanan (2017)/Source: Ministry of Marine Affairs and Fisheries (2017)

Jumlah kapal perikanan yang terbesar adalah kapal perikanan menggunakan alat tangkap pancing cumi dan selanjutnya jaring insang oseanik. Armada kapal perikanan yang memiliki rata-rata ukuran GT yang terbesar adalah kapal perikanan menggunakan alat tangkap purse seine yaitu 140 GT. Secara keseluruhan, rata-rata ukuran kapal perikanan (>30 GT) yang beroperasi di Perairan Arafura adalah 92 GT. Setiap jenis alat tangkap memiliki spesies target tangkapan yang berbeda dan memiliki tingkat produktivitas yang berbeda pula. Kapal perikanan dengan menggunakan alat tangkap purse seine dan jaring insang oseanik bertujuan untuk menangkap ikan pelagis, sedangkan pancing rawai dasar digunakan untuk menangkap ikan demersal, serta pancing cumi untuk menangkap cumi-cumi. Berdasarkan Keputusan Menteri Kelautan dan Perikanan No. 86 tahun 2016, tentang produktivitas kapal perikanan di Indonesia, maka kapal perikanan dengan menggunakan alat tangkap purse seine memiliki produktivitas paling tinggi dibandingkan kapal perikanan dengan alat tangkap lainnya. Produktivitas masing-masing alat tangkap disajikan pada Tabel 3.

Jumlah produksi ikan di WPP 718 secara keseluruhan mengalami penurunan dari tahun 2014 ke tahun 2015 , yaitu sebesar $38 \%$. Penurunan tertinggi secara persentase adalah kelompok lobster (349\%) dan dari segi jumlah, penurunan tertinggi adalah kelompok jenis ikan demersal (146\%). Penurunan jumlah produksi ini disebabkan karena sudah tidak beroperasinya jenis alat tangkap pukat udang dan pukat ikan yang memiliki produktivitas tinggi untuk menangkap ikan demersal. Namun, produksi jenis ikan karang, pelagis kecil, pelagis besar dan rajungan mengalami peningkatan dengan jumlah yang lebih kecil dibandingkan jumlah penurunan ikan demersal. Hal ini disebabkan karena berkembangnya penggunakan alat tangkap jaring insang oseanik dan purse seine di WPP 718 , dengan target tangkapan jenis ikan pelagis. Produksi ikan menurut kelompok jenis ikan tahun 2014 dan 2015 disajikan pada Tabel 4.

\section{Analisis Bioekonomi}

Jenis alat tangkap kapal perikanan yang beroperasi di Laut Arafura mengalami perubahan yang sangat signifikan semenjak diberlakukannya Peraturan Menteri Kelautan dan Perikanan no 56 tahun 2014 dan no 2 tahun 2015. Dengan kebijakan tersebut, pelaku usaha perikanan juga mengalami perubahan, industri pengolahan tidak mendapatkan pasokan yang cukup dan penggunaan tenaga kerja semakin diperketat. Kapal pukat udang dan pukat ikan melakukan usaha penangkapan skala besar, menghasilkan produk hasil perikanan dengan kualitas tinggi dan sebagian besar menggunakan tenaga kerja asing. Nelayan tradisional/lokal hanya melakukan penangkapan skala kecil, serta hasil tangkapan untuk pasar lokal. Setelah adanya kebijakan tersebut, usaha penangkapan ikan dilakukan oleh nelayan dengan menggunakan kapal perikanan yang dibangun didalam negeri. 
Tabel 4. Jumlah Produksi Menurut Kelompok Jenis Ikan di WPP 718, tahun 2014-2015. Table 4. Fish Production Based on Type of Fish Group in WPP 718, 2014-2015.

\begin{tabular}{clrrr}
\hline \multirow{2}{*}{ No } & \multicolumn{1}{c}{$\begin{array}{c}\text { Jenis Kelompok Ikan/ } \\
\text { Type of fish group }\end{array}$} & \multicolumn{2}{c}{ Produksi/Production } & $\begin{array}{c}\text { Perubahan/ Rate } \\
\text { of Changes (\%) }\end{array}$ \\
\cline { 3 - 4 } & Ikan pelagis kecil/Small pelagic & $\mathbf{2 0 1 4}$ & $\mathbf{2 0 1 5}$ & $32.59 \%$ \\
2 & ikan pelagis besar/Big pelagic & 33,191 & 59,681 & $29.57 \%$ \\
3 & Ikan demersal/Demersal & 165,729 & 67,126 & $-146.12 \%$ \\
4 & Ikan karang/Coral fish & 7,788 & 16,157 & $51.80 \%$ \\
5 & Udang Penaeid/Crustaceans & 7,238 & 6,259 & $-15.64 \%$ \\
6 & Lobster/Lobster & 755 & 168 & $-349.40 \%$ \\
7 & Kepiting/Mangrove mud crab & 1,712 & 1,431 & $-19.64 \%$ \\
8 & Rajungan/Swimming crab & 1,496 & 1,768 & $15.38 \%$ \\
9 & Cumi-cumi/Common squids & 3,030 & 7,340 & $58.72 \%$ \\
\hline \multicolumn{2}{c}{ Jumlah/ Total/Rata-ratal/Average } & $\mathbf{2 6 1 , 1 6 7}$ & $\mathbf{2 0 7 , 2 6 7}$ & $\mathbf{- 3 8 . 0 8 \%}$ \\
\hline
\end{tabular}

Sumber: Direktorat Pengelolaan Sumberdaya Ikan, DJPT (2017)/Source: Directorate Fishery Resources Management (2017)

Ukuran armada penangkapan yang digunakan dengan kategori sedang (60 GT - $200 \mathrm{GT}$ ) dengan rata-rata 92 GT (Kementerian Kelautan dan Perikanan, 2017).

Penelitian ini menggunakan analisis bioekonomi untuk mengetahui tingkat optimal pemanfaatan sumber daya ikan demersal di Laut Arafura. Sebelum adanya kebijakan pemerintah tersebut, alat tangkap yang banyak digunakan adalah alat tangkap pukat (trawls), dan setelah kebijakan, alat angkap yang dioperasikan oleh nelayan untuk menangkap ikan demersal adalah pancing rawai dasar. Analisis bioekonomi menggunakan parameter biologi dan parameter ekonomi. Parameter biologi yang digunakan adalah tingkat pertumbuhan intrinsik ikan, koefisien kemampuan menangkap dan daya dukung lingkungan untuk perikanan tersebut. Parameter ekonomi yang digunakan adalah biaya penangkapan menggunakan alat tangkap standar, rata-rata harga ikan dan indeks harga konsumen. Model surplus produksi paling baik yang dihasilkan dari data yang digunakan adalah Model Walters \& Hilborn (1976).

Analisis pertama dilakukan dengan menggunakan alat tangkap pukat sebagai alat tangkap standar serta jumlah pancing rawai dasar distandarkan ke alat tangkap pukat. Rata-rata ukuran kapal perikanan dengan menggunakan alat tangkap pukat adalah 180 GT (Purwanto, 2013). Rata-rata ukuran kapal perikanan dengan alat tangkap pancing rawai dasar adalah 75 GT.
Rata-rata produktivitas kapal pukat adalah 2 ton/ GT kapal per tahun dan rata-rata produktivitas kapal pancing rawai dasar satu ton/GT kapal/ tahun. Perkembangan jumlah produksi, jumlah alat tangkap untuk menangkap ikan demersal dengan alat tangkap standar pukat dan pancing rawai dasar serta catch per unit effort (CPUE) per kapal (Tabel 5).

Data runtun waktu yang digunakan untuk menduga parameter biologi ikan demersal di Perairan LautArafura adalah datatahun 2001 sampai dengan tahun 2014. Data jumlah produksi terdiri dari seluruh jenis ikan demersal dan udang yang telah dikelompokkan menurut wilayah pengelolaan perikanan 718. Jumlah produksi merupakan hasil tangkapan yang dilaporkan dan tercatat secara statistik. Data jumlah kapal pukat adalah kapal pukat yang mendapat izin penangkapan di WPP 718, sedangkan kapal pancing rawai dasar terdiri dari kapal perikanan mulai dari yang berukuran kecil sampai dengan yang berukuran besar. Jumlah kapal pukat diperoleh dari seluruh GT kapal (pukat dan pancing rawai dasar) dibagi dengan $180 \mathrm{GT}$, sedangkan untuk jumlah kapal pancing rawai dasar dibagi dengan 75 GT. Pada penelitian ini, analisis dilakukan terhadap kapal dengan kedua jenis alat tangkap tersebut secara terpisah, untuk mengetahui tingkat optimal pemanfaatan ikan demersal dengan kapal pukat dan tanpa kapal pukat.

Secara keseluruhan, model regresi linier berganda yang dihasilkan signifikan pada nilai $\alpha=0,05$, dengan uji $\mathrm{F} 5,67$. Korelasi antara 
Tabel 5. Jumlah Produksi, Jumlah Kapal Pukat dan Pancing Rawai Dasar dan Jumlah Hasil Tangkapan Per Kapal di Laut Arafura.

Table 5. Productions, Trawls, Set Longlines and Catch Per Unit Trawl in Arafura Sea.

\begin{tabular}{cccccc}
\hline \multirow{2}{*}{$\begin{array}{c}\text { Tahun/ } \\
\text { Year }\end{array}$} & $\begin{array}{c}\text { Produksi/ } \\
\text { Production }\end{array}$ & \multicolumn{2}{c}{$\begin{array}{c}\text { Jumlah Kapall } \\
\text { Number of Vessel }\end{array}$} & \multicolumn{2}{c}{$\begin{array}{c}\text { CPUE (Ton/Unit Kapal)/ } \\
\text { CPUE (Ton/Ship Unit)/ }\end{array}$} \\
\cline { 3 - 6 } & & Pukat/Trawls & $\begin{array}{c}\text { Pancing Rawai Dasar/ } \\
\text { Set Longline }\end{array}$ & $\begin{array}{c}\text { Pukat/ } \\
\text { Trawls }\end{array}$ & $\begin{array}{c}\text { Pancing Rawai Dasarl } \\
\text { Set Longline }\end{array}$ \\
\hline 2001 & 119,400 & 790 & 1,926 & 151.09 & 62.00 \\
2002 & 127,700 & 819 & 2,047 & 155.87 & 62.39 \\
2003 & 141,200 & 830 & 2,069 & 170.20 & 68.25 \\
2004 & 194,900 & 1,071 & 2,605 & 181.94 & 74.82 \\
2005 & 198,700 & 1,291 & 3,135 & 153.95 & 63.37 \\
2006 & 116,395 & 1,376 & 3,344 & 84.61 & 34.81 \\
2007 & 131,700 & 952 & 2,329 & 138.34 & 56.54 \\
2008 & 95,471 & 919 & 2,247 & 103.90 & 42.49 \\
2009 & 96,998 & 670 & 1,677 & 144.86 & 57.85 \\
2010 & 160,773 & 850 & 2,111 & 189.11 & 76.16 \\
2011 & 119,383 & 907 & 2,269 & 131.65 & 52.62 \\
2012 & 106,164 & 938 & 2,356 & 113.20 & 45.06 \\
2013 & 104,616 & 958 & 2,437 & 109.18 & 42.92 \\
2014 & 172,967 & 947 & 2,516 & 182.69 & 68.74 \\
\hline
\end{tabular}

Sumber: Kementerian Kelautan dan Perikanan (2016)/Source: Ministry of Marine Affairs and Fisheries (2016)

variabel $\mathrm{Y}$ dengan variabel bebas sebesar $72,90 \%$ dan koefisien determinasi sebesar 53,14\% (untuk kapal pukat). Dengan menggunakan model surplus produksi Walters dan Hilborn untuk data yang dimiliki maka variabel tidak bebas $\left(\frac{U_{t+1}}{U_{t}}-1\right)$ dapat dijelaskan oleh variabel $U_{t}$ dan $E_{t}$ sebagai variabel bebas sebesar $53,14 \%$, sedangkan $46,86 \%$ lainnya dijelaskan oleh variabel lain. Uji tanda untuk hasil regresi linier berganda telah sesuai dengan tanda pada model yaitu bertanda negatif baik untuk variabel $U_{t}$ maupun $E_{t}$. Pada persamaan diatas, nilai dalam tanda kurung menunjukkan nilai uji t, dimana variabel $U_{t}$ signikan pada nilai $\alpha=0,05$, sedangkan variabel $E_{t}$ hanya signifikan pada nilai $\alpha=0,30$. Persamaan hasil regresi menggunakan model Walters dan Hilborn dengan regresi berganda (informasi dalam kurung menunjukkan nilai uji $\mathrm{t}$, ${ }^{* * *}$ menunjukkan variabel signifikan pada $\alpha=0,05$, * menunjukkan variabel signifikan pada $\alpha=0,30$.

$$
\begin{array}{r}
Y=1,7201-0,0087 * * * U_{t}-0,0005 * E_{t} \\
(-3,37) \quad(-1,10)
\end{array}
$$

Pada model Walters dan Hilborn, nilai konstanta atau $\beta_{0}$ dalam persamaan regresi menunjukkan nilai tingkat pertumbuhan intrinsik ikan $(r)$, serta nilai $\beta_{2}$ menunjukkan nilai koefisien kemampuan tangkap alat tangkap yang digunakan (q). sedangkan nilai daya dukuns lingkı ıngan (K) dapat diduga dari perhitungan $K=\frac{\beta_{0}}{\beta_{1} \beta_{2}}$ atau $K=\frac{r}{q \beta_{1}}$. Secara lengkap besar nilai parameter biologi disajikan Tabel 6 .

Tingkat pertumbuhan intrinsik ikan demersal di WPP 718 adalah 1,72. Nilai ini menunjukkan distribusi umur dari populasi ikan yang dianalisis cukup lebar, karena perbedaan umur diantara jenis ikan bervariasi. Kakap merupakan salah satu contoh ikan demersal yang memiliki tingkat pertumbuhan lambat dan juga tingat kematian rendah. Pada umumnya umur maksimum ikan kakap lebih dari 10 tahun (Brule et al., 2018). Sedangkan umur maksimum udang adalah 5 tahun (Yamaguchi et al., 2014). Nilai cathability coefficient diperoleh sebesar 0,000455 , serta daya dukung perairan untuk perikanan demersal adalah 435.371 ton per tahun. Besaran daya dukung menunjukkan banyaknya jumlah ikan yang dapat ditampung oleh perairan, dimana ikan tersebut dapat tumbuh dan berkembang maksimum.

Pendugaan parameter selanjutnya adalah untuk kapal perikanan menggunakan alat tangkap pancing rawai dasar sebagai alat tangkap standar. Proses yang dilakukan untuk menentukan jumlah alat tangkap standar sama seperti yang dilakukan terhadap kapal pukat. Produktivitas kapal perikanan 
dengan alat tangkap pukat lebih besar dari produktivitas kapal perikanan dengan alat tangkap pancing rawai dasar, sehingga jumlah alat tangkap pancing rawai dasar menjadi lebih besar (Tabel 5).

Model regresi linier berganda yang dihasilkan juga signikan pada nilai $\alpha=0,05$, dengan uji $\mathrm{F}$ 5,46 . Korelasi antara variabel $Y$ dengan variabel bebas sebesar $72,26 \%$ dan koefisien determinasi sebesar 52,21\% (untuk kapal pancing rawai dasar). Dengan menggunakan model surplus produksi Walters dan Hilborn untuk data yang dimiliki maka variabel tidak bebas $\left(\frac{U_{t+1}}{-1}-1\right)$ dapat dijelaskan oleh variabel $U_{t}$ dan $E_{t}{ }^{-T}$ sebagai variabel bebas sebesar $52,21 \%$, sedangkan $47,79 \%$ lainnya dijelaskan oleh variabel lain. Uji tanda untuk hasil regresi linier berganda telah sesuai dengan tanda pada model yaitu bertanda negatif baik untuk variabel $U_{t}$ maupun $E_{t}$. Pada persamaan diatas, nilai dalam tanda kurung menunjukkan nilai uji $\mathrm{t}$, dimana variabel $U_{t}$ signikan pada nilai $\alpha=0,05$, sedangkan variabel $E_{t}$ hanya signifikan pada nilai $\alpha=0,30$. Persamaan hasil regresi untuk kapal dengan pancing rawai dasar yaitu:

$$
\begin{array}{r}
Y=1,5947-0,0202 U_{t}-0,00016 E_{t} \\
(-3,30) * * *(-0,97) *
\end{array}
$$

Angka dalam kurung menunjukkan nilai uji t, dimana variabel $U_{t}$ signifikan pada nilai $\alpha=0,05$, sedangkan variabel $E_{t}$ hanya signifikan pada nilai $\alpha=0,40$. Dari koefisien yang diperoleh maka parameter biologi untuk alat tangkap pancing rawai dasar diperoleh seperti pada Tabel 6.
Parameter ekonomi yang dibutuhkan dalam penelitian ini adalah struktur biaya penangkapan dan harga ikan. Struktur biaya penangkapan mengacu pada struktur biaya penangkapan menggunakan pukat udang dan pukat ikan di Arafura yang dilakukan pada tahun 2012. Sebesar $70 \%$ biaya penangkapan terdiri dari biaya untuk bahan bakar minyak. Bahan bakar minyak yang digunakan oleh kapal perikanan dengan alat tangkap pukat adalah solar dengan tingkat penggunaan berkisar antara 60.000 liter sampai 90.000 liter per trip Harga bahan bakar solar mengacu pada harga solar untuk industri yang ditetapkan oleh pemerintah. Pada tahun 2012 harga solar sebesar 12.350 per liter sedangkan pada tahun 2014 harga solar untuk industri di wilayah IV adalah 8.950 per liter. Biaya penangkapan untuk melakukan penangkapan ikan di WPP 718 oleh kapal perikanan pukat udang dan pukat ikan bervariasi, namun data yang digunakan pada penelitian ini adalah biaya ratarata dengan harga solar industri pada tahun 2014 sehingga diperoleh biaya operasional penangkapan menggunakan alat tangkap pukat adalah Rp1.323,21 juta atau 1,32 milyar rupiah per trip

Struktur biaya penangkapan dengan alat tangkap pancing rawai dasar menggunakan data hasil penelitian yang dilakukan Kisworo et al. (2013). Penelitian dilakukan pada tahun 2012 menggunakan alat tangkap pancing rawai dasar. Total biaya yang disampaikan pada jurnal tersebut merupakan data biaya penangkapan per tahun, sedangkan dalam penelitian ini menggunakan

Tabel 6. Nilai Parameter Biologi dan Ekonomi Perikanan Demersal di WPP 718 Dengan Alat Tangkap Pukat dan Pancing Rawai Dasar.

Table 6. Biological and Economical Parameters of Demersal Fish in WPP 718 Used Trawls

\begin{tabular}{|c|c|c|c|c|}
\hline \multirow[b]{2}{*}{ No } & \multirow[b]{2}{*}{$\begin{array}{l}\text { Koefisien/ } \\
\text { Coefficient }\end{array}$} & \multirow[b]{2}{*}{ Definisi/Definition } & \multicolumn{2}{|c|}{ Nilai/value } \\
\hline & & & Pukat/Trawl & $\begin{array}{l}\text { Pancing Rawai Dasarl } \\
\text { Set Long Line }\end{array}$ \\
\hline 1 & $r$ & $\begin{array}{l}\text { Tingkat pertumbuhan intrinsic / } \\
\text { Intrinsic Growth Rate }\end{array}$ & 1.720052 & 1.594739 \\
\hline 2 & $q$ & $\begin{array}{l}\text { Koefisien Kemampuan tangkap/ } \\
\text { Catchability coefficient }\end{array}$ & 0.000455 & 0.000166 \\
\hline 3 & K & $\begin{array}{l}\text { Daya dukung perairan (ton/tahun)/ } \\
\text { Carrying capacity (ton/year) }\end{array}$ & 435,371 & 477,027 \\
\hline 4 & c & $\begin{array}{l}\text { Biaya penangkapan (juta rupiah/ } \\
\text { trip)/ Cost of fishing (IDR/ trip) }\end{array}$ & $1,323.21$ & 192.82 \\
\hline 5 & $P$ & $\begin{array}{l}\text { Harga ikan (juta rupiah/ton)/ Price of } \\
\text { fish/(IDR/ton) }\end{array}$ & 27.87 & 27.87 \\
\hline
\end{tabular}
and Set Long Lines.

Sumber: Hasil analisis data (2018)/Source: Results of data analysis (2018) 
biaya penangkapan per trip. Dengan asumsi kapal perikanan dengan alat tangkap pancing melakukan operasi penangkapan lebih dari 30 hari, maka rata-rata jumlah trip per tahun adalah 5. Setelah data biaya per trip diperoleh maka, untuk menyetarakan data yang digunakan dikalikan dengan indeks harga konsumen. Dengan demikian diperoleh biaya penangkapan penggunakan alat tangkap pancing rawai dasar per trip pada tahun 2014 adalah 192,82 juta rupiah.

Harga ikan yang digunakan dalam penelitian ini meliputi harga ikan bawal (hitam dan putih) kakap (merah dan putih), manyung, kuwe, kuro dan seluruh jenis udang (putih, dogol, windu dan lainnya). Rata-rata harga dari semua jenis ikan tersebut semenjak tahun 2001 sampai tahun 2014. Supaya harga ikan dapat diperbandingkan untuk setiap tahunnya, maka harga nominal tersebut dikalikan dengan indeks harga konsumen setiap tahun yang telah mempertimbangkan nilai inflasi. Indeks harga konsumen yang digunakan adalah indeks harga dengan tahun dasar tahun 2007=100. Dengan demikian, indeks harga sebelum tahun 2007 lebih rendah dari 100 dan indeks harga setelah tahun 2007 lebih dari 100 . Indeks harga tahun 2014 adalah 145,30 dengan tahun dasar tahun 2007. Harga yang digunakan sebagai harga patokan adalah harga tahun 2014 karena seluruh analisis dilakukan pada tahun tersebut. Rata-rata harga adalah 27,87 juta per ton.

Dengan menggunakan parameter biologi dan parameter ekonomi untuk masing-masing alat tangkap yang digunakan sebagai alat tangkap standar, maka pada kondisi tidak adanya pengelolaan yang diterapkan (open access), maka kondisi stok ikan demersal ketika menggunakan alat tangkap pukat lebih tinggi dibandingkan jumlah stok ketika menggunakan alat tangkap pancing rawai dasar. Jumlah hasil tangkapan yang dapat dihasilkan oleh alat tangkap pukat adalah 136.399 ton per tahun dengan alat tangkap
2.873 unit. Pada saat adanya larangan penggunaan pukat, dengan asumsi hanya alat tangkap pancing rawai yang beroperasi, jumah alat tangkap pancing yang dapat dioperasikan sebanyak 8.787 unit. Dalam kondisi open access, penggunaan alat tangkap pancing rawai menyebabkan pengurasan sumber daya yang lebih besar dibandingkan menggunakan pukat, hal ini disebabkan karena banyaknya kapal yang beroperasi, sehingga menghambat perkembangbiakan ikan, pertumbuhan ikan menjadi rendah, dan jumlah stok terus mengalami penurunan. Hal demikian tidak terjadi di wilayah pengelolaan perikanan Indonesia, karena Indonesia menerapkan semi open access, dengan menetapkan sejumlah aturan untuk kapal perikanan dengan ukuran lebih dari $10 \mathrm{GT}$. Jumlah stok, hasil tangkapan dan jumlah alat tangkap pada pengelolaan open access disajikan pada Tabel 7. Pada pengelolaan open access, pelaku usaha tidak mendapatkan rente ekonomi.

Pengelolaan sumber daya perikanan dengan optimum secara biologi (MSY) menunjukkan bahwa kapal perikanan menggunakan alat tangkap pancing rawai dasar lebih ramah dibandingkan menggunakan kapal pukat, hal ini dapat dilihat dari jumlah stok/biomas dan jumlah hasil tangkapan yang lebih tinggi (Tabel 8). Jumlah stok/biomas memiliki nilai yang lebih tinggi disebabkan karena parameter biologi daya dukung lingkungan menggunakan alat tangkap pancing rawai dasar lebih tinggi dibandingkan menggunakan kapal pukat. Sehingga jumlah kapal yang diperbolehkan untuk melakukan penangkapan lebih banyak, hasil tangkapan menjadi lebih tinggi dan rente yang diperoleh juga lebih tinggi. Moratorium kapal perikanan asing di Indonesia yang menyebabkan berkurangnya kapal pukat (trawl) di WPP 718 secara biologi dapat memperbaiki ekosistem perairan karena tingkat pemanfaatan yang dilakukan masih lebih rendah dibandingkan tingkat optimal. Namun memberikan manfaat ekonomi yang lebih rendah karena sebagian potensi ikan tidak termanfaatkan.

Tabel 7. Jumlah Stok, Jumlah Hasil Tangkapan dan Jumlah Alat Tangkap Pada Open Access. Table 7. Biomass, Harvest and Fishing Gear Number st Open Access.

\begin{tabular}{clccc}
\hline $\begin{array}{c}\text { Simbol I } \\
\text { Symbol }\end{array}$ & \multicolumn{1}{c}{$\begin{array}{c}\text { Definisi/ } \\
\text { Definition }\end{array}$} & Satuan/Unit & $\begin{array}{c}\text { Pukat / } \\
\text { Trawl }\end{array}$ & $\begin{array}{c}\text { Pancing Rawai Dasarl } \\
\text { Set Long Line }\end{array}$ \\
\hline X & Stok/Biomass & ton & 104,273 & 41,780 \\
h & Hasil tangkapan/Harvest & ton & 136,399 & 60,792 \\
E & Jumlah alat tangkap/Effort & unit & 2,873 & 8,787 \\
\hline
\end{tabular}

Sumber: Hasil analisis data (2018)/Source: Results of data analysis (2018) 
Tabel 8. Jumlah Stok, Jumlah Hasil Tangkapan dan Jumlah Alat Tangkap Pada MSY.

Table 8. Biomass, Harvest and Fishing Gear Number at MSY.

\begin{tabular}{clccc}
\hline $\begin{array}{c}\text { Simbol / } \\
\text { Symbol }\end{array}$ & \multicolumn{1}{c}{$\begin{array}{c}\text { Definisi/ } \\
\text { Definition }\end{array}$} & $\begin{array}{c}\text { Satuan/ } \\
\text { Unit }\end{array}$ & $\begin{array}{c}\text { Pukat / } \\
\text { Trawl }\end{array}$ & $\begin{array}{c}\text { Pancing Rawai Dasar/ } \\
\text { Set Long Line }\end{array}$ \\
\hline $\mathrm{X}$ & Stok/Biomass & ton & 217,686 & 238,514 \\
$\mathrm{~h}$ & Hasil tangkapan/Harvest & ton & 187,215 & 190,184 \\
$\mathrm{E}$ & Jumlah alat tangkap/Effort & unit & 1,889 & 4,815 \\
$\mathrm{Phi}$ & Rente/ Rent & Rp (juta) & $2,718,380$ & $4,371,959$ \\
\hline
\end{tabular}

Sumber: Hasil analisis data (2018)/Source: Results of data analysis (2018)

Tabel 9. Jumlah Stok, Jumlah Hasil Tangkapan dan Jumlah Alat Tangkap Pada MEY. Table 9. Biomass, Harvest and Fishing Gear Number at MEY.

\begin{tabular}{clcrr}
\hline $\begin{array}{c}\text { Simbol/ } \\
\text { Symbol }\end{array}$ & \multicolumn{1}{c}{$\begin{array}{c}\text { Definisi/ } \\
\text { Definition }\end{array}$} & $\begin{array}{c}\text { Satuan/ } \\
\text { Unit }\end{array}$ & $\begin{array}{c}\text { Pukat I } \\
\text { Trawl }\end{array}$ & $\begin{array}{c}\text { Pancing Rawai Dasarl } \\
\text { Set Long Line }\end{array}$ \\
\hline X & Stok/Biomass & ton & 269,822 & 259,404 \\
h & Hasil tangkapan/Harvest & ton & 176,476 & 188,725 \\
E & Jumlah alat tangkap/Effort & unit & 1,436 & 4,393 \\
Phi & Rente/Rent & Rp (juta) & $3,017,677$ & $4,412,618$ \\
\hline
\end{tabular}

Sumber: Hasil analisis data (2018)/Source: Results of data analysis (2018)

Penentuan tingkat optimal secara ekonomi dipengaruhi oleh parameter ekonomi dan juga parameter biologi. Maksimum rente ekonomi dapat dicapai dengan tidak mengabaikan faktor biologi, sehingga jumlah stok/biomas dan rente ekonomi pada kondisi MEY lebih tinggi dibandingkan MSY, namun jumlah kapal dan produksi lebih rendah. Ditinjau dari segi ekonomis, produktivitas kapal pukat lebih tinggi dibandingkan kapal pancing rawai, namun memerlukan biaya operasional yang jauh lebih tinggi, sehingga jumlah kapal yang diperbolehkan untuk beroperasi lebih sedikit, yang memberikan total jumlah produksi lebih rendah, maka rente ekonomi kapal pukat menjadi lebih rendah (Tabel 9). Jumlah kapal dengan alat tangkap pancing rawai lebih tinggi, sehingga memberikan jumlah produksi lebih tinggi, namun menyebabkan berkurangnya jumlah stok/biomas.

Kebijakan moratorium kapal asing yang menyebabkan dilarangnya kapal perikanan yang dibangun di luar negeri untuk beroperasi di wilayah pengelolaan perikanan Indonesia, maka sebanyak 614 kapal pukat sudah tidak beroperasi di WPP 718 untuk melakukan penangkapan ikan demersal. Berdasarkan hasil penelitian, pengelolaan maksimum secara ekonomi (MEY) merupakan jenis pengelolaan terbaik yang memberikan rente tertinggi dan juga stok/biomas paling baik. Menurut Keputusan Menteri Kelautan No 50 tahun 2017, tingkat pemanfaatan ikan demersal di WPP 718 sebesar $67 \%$ dari jumlah tangkapan yang diperbolehkan. Dalam upaya mencapai tingkat pemanfaatan optimal secara ekonomi maka perlu penambahan pancing rawai dasar sebanyak 1.450 unit atau 33\% dari total jumlah kapal optimal. Biaya investasi untuk setiap unit kapal perikanan dengan alat tangkap pancing rawai dasar sebesar 953,74 juta rupiah. Total investasi yang dibutuhkan untuk mencapai jumlah effort optimal adalah 1,38 trilyun rupiah (Tabel 10).

Jumlah produksi yang telah dihasilkan adalah 126,66 ribu ton. Menggunakan rata-rata harga ikan demersal pada tahun 2017 yaitu 32.06 juta/ton, maka total penerimaan adalah 4,05 trilyun per tahun. Biaya operasional penangkapan ikan menggunakan alat tangkap pancing rawai dasar adalah 221,83 juta rupiah, maka diperoleh total biaya penangkapan dari seluruh kapal yang telah beroperasi adalah 652,97 milyar per tahun. Dengan demikian total rente yang diperoleh sebesar 3,40 trilyun atau $77,07 \%$ dari total rente maksimum secara ekonomi. 
Tabel 10. Jumlah Kapal, Investasi dan Rente Ekonomi Ikan Demersal di WPP 718, 2017. Table 10. Number of Set Long Lines, Investmens and Economi Rents Demersal Fishery in WPP 718, 2017.

\begin{tabular}{lcc}
\hline \multicolumn{1}{c}{ Keterangan/Remaks } & Satuan/Unit & Jumlah/Total \\
\hline Tingkat pemanfaatan/Utilization rate & $\%$ & 67 \\
Jumlah pancing rawai dasar/Number of set longline & Unit & 2,944 \\
Tambahan pancing rawai dasar/Lack of optimal level & Unit & 1,450 \\
Investasi/Investments & Juta/unit & 953 \\
Kebutuhan Investasi/Investment needed & Juta & $1,381,305$ \\
Produksi/Productions & Ton & 126,446 \\
Rata-rata harga/Average price & Juta/ton & 32 \\
Penerimaan/Total revenue & Juta & $4,053,900$ \\
Biaya operasional/Cost of fishing & Juta & 221.83 \\
Total biaya/Total cost & Juta & 652.973 \\
Rente/Rent & Juta & $3,400,927$ \\
\hline
\end{tabular}

Sumber: Hasil analisis data (2018)/Source: Results of data analysis (2018)

\section{KESIMPULAN DAN IMPLIKASI KEBIJAKAN}

\section{Kesimpulan}

Tingkat pemanfaatan sumber daya perikanan demersal di Laut Arafura sebelum kebijakan moratorium kapal asing, telah mendekati kondisi optimal, bahkan sebagian literatur menunjukkan telah terjadi kelebihan tangkap, karena banyaknya kapal perikanan tanpa izin yang melakukan penangkapan. Kebijakan moratorium kapal asing yang menyebabkan dilarangnya kapal perikanan yang dibangun di luar negeri untuk beroperasi di wilayah pengelolaan perikanan Indonesia, maka sebanyak 614 kapal pukat sudah tidak beroperasi di WPP 718 untuk melakukan penangkapan ikan demersal. Berdasarkan hasil penelitian, pengelolaan maksimum secara ekonomi (MEY) merupakan jenis pengelolaan terbaik yang memberikan rente tertinggi dan juga stok/biomas paling baik. Menurut Keputusan Menteri Kelautan No 50 tahun 2017, tingkat pemanfaatan ikan demersal di WPP 718 sebesar $67 \%$ dari jumlah tangkapan yang diperbolehkan. Dalam upaya mencapai tingkat pemanfaatan optimal secara ekonomi maka perlu penambahan pancing rawai dasar sebanyak 1.450 unit atau 33\% dari total jumlah kapal optimal. Biaya investasi untuk setiap unit kapal perikanan dengan alat tangkap pancing rawai dasar sebesar 953,74 juta rupiah. Total investasi yang dibutuhkan untuk mencapai jumlah effort optimal adalah 1,38 trilyun rupiah (Tabel 10).
Jumlah produksi yang telah dihasilkan adalah 126,66 ribu ton. Menggunakan rata-rata harga ikan demersal pada tahun 2017 yaitu 32.06 juta/ton, maka total penerimaan adalah 4,05 trilyun per tahun. Biaya operasional penangkapan ikan menggunakan alat tangkap pancing rawai dasar adalah 221,83 juta rupiah, maka diperoleh total biaya penangkapan dari seluruh kapal yang telah beroperasi adalah 652,97 milyar per tahun. Dengan demikian total rente yang diperoleh sebesar 3,40 trilyun atau $77,07 \%$ dari total rente maksimum secara ekonomi.

\section{Implikasi Kebijakan}

Laut Arafura sudah sangat terkenal memiliki potensi sumber daya perikanan terbesar di Indonesia. Kebijakan moratorium kapal perikanan asing telah menyebabkan turunnya jumlah produksi, turunnya jumlah ekspor sehingga turunnya devisa negara dari perikanan. Dalam upaya mencapai tingkat pemanfaatan secara optimal yang memberikan rente maksimum, maka diperlukan tambahan jumlah kapal yang beroperasi di WPP 718. Salah satu cara yang dapat dilakukan adalah dengan relokasi penangkapan bagi kapal perikanan yang menangkap ikan di WPP lainnya, serta memberikan kemudahankemudahan kepada pengusaha perikanan nasional untuk memperoleh izin penangkapan di WPP 718. 
Produk hasil perikanan merupakan produk yang sangat mudah rusak, maka penanganan pasca panen sampai ikan dikonsumsi harus dilakukan dengan baik, oleh karena itu diperlukan prasarana dan sarana penangkapan, penanganan dan pemasaran yang memadai. Pengolahan dan pemasaran hasil perikanan terpusat di Pulau Jawa, transportasi dan distribusi ikan membutuhkan waktu yang lama dan biaya yang tinggi. Oleh karena itu diperlukan penyediaan infrastruktur untuk pengolahan ikan menjadi produk olahan setengah jadi, sehingga diperoleh nilai tambah dan rente ekonomi yang lebih tinggi.

\section{UCAPAN TERIMA KASIH}

Terima kasih disampaikan kepada Prof. Sonny Koeshendrajana, Dr Umi Muawanah Yayan Hikmayani, M.Si dan rekan-rekan Balai Besar Sosial Ekonomi Kelautan dan Perikanan atas semua bantuan dan dukungan baik berupa data, metode, materi, kesempatan maupun dukungan lainnya, sehingga artikel ini dapat diterbitkan.

\section{DAFTAR PUSTAKA}

Anderson, L.G. 1985. Potential Economic Benefits from Gear Restriction and License Limitation In Fisheries Regulation. Land Economics.

Asano, A, K. Neill, and S. Yamazaki. 2016. Decomposing Fishing Effort: Modelling The Sources Of Inefficiency In A Limited Entry Fishery. (Discussion Paper). The University of Western Australia.

Brule, T., C.M. Teresa, P.D. Esperanza and D. Christian. 2018. Biology, Exploitation and Management of Groupers (Serranidae, Epinephelinae, Epinephelini) And Snappers (Lutjanidae, Lutjaninae, Lutjanus) In The Gulf Of Mexico. Https://Www.Harteresearchinstitute.Org/Sites/ Default/Files/Inline-Files/8.Pdf.

Campbell, H.F and R.K. Lindner. 1990. The Production of Fishing Effort and Economic Performance of Licence Limitation Programs. Land Economics

Clark, C.W. 1990. Mathematical Bioeconomic The Optimal of Renewable Resources. Wiley Interscience- Paperback Series.

Direktorat Pengelolaan Sumber Daya Ikan, DJPT 2017. Statistik produksi ikan berdasarkan wilayah pengelolaan perikanan tahun 2011-2015.

Grainger, C.A and D.P. Parker. 2013. The Political Economy of Fishery Reform. Department Of Agricultural And Applied Economics, University Of Wisconsin, Madison, Wisconsin 53706; Https:// Aae.Wisc.Edu/Cagrainger /Pol_Economy_ Fisheries.Pdf
Hilborn, R. and C.J. Walters, 1992. Quantitative Fisheries Stock Assessment: Choice, Dynamical and Uncertainty. Chapman and Hall, Inc., New York

Kementerian Kelautan dan Perikanan Republik Indonesia. 2014. Peraturan Menteri Kelautan Dan Perikanan Nomor 56/Permen-Kp/2014 Tentang Penghentian Sementara (Moratorium) Perizinan Usaha Perikanan Tangkap di Wilayah Pengelolaan Perikanan Negara Republik Indonesia.

Kementerian Kelautan dan Perikanan Republik Indonesia. 2015. Peraturan Menteri Kelautan Dan Perikanan Nomor 02/Permen-Kp/2015 Tentang Larangan Penggunaan Alat Penangkapan Ikan Pukat Hela (Trawls) Dan Pukat Tarik (Seine Nets) Di Wilayah Pengelolaan Perikanan Negara Republik Indonesia.

Kementerian Kelautan dan Perikanan Republik Indonesia. 2016. Keputusan Menteri Kelautan Dan Perikanan Nomor 86/Kepmen-Kp/2016 Tentang Produktivitas Kapal Penangkap Ikan.

Kementerian Kelautan dan Perikanan. 2016. Statistik Perikanan Tangkap Indonesia, 2009-2014.

Kementerian Kelautan dan Perikanan Republik Indonesia. 2017. Keputusan Menteri Kelautan Dan Perikanan Nomor 50/Kepmen-Kp/2017 Tentang Estimasi Potensi, Jumlah Tangkapan Yang Diperbolehkan, Dan Tingkat Pemanfaatan Sumber Daya Ikan di Wilayah Pengelolaan Perikanan Negara Republik Indonesia

Kementerian Kelautan dan Perikanan. 2017. Perizinan kapal perikanan di Indonesia. http://www. perizinan.kkp.go.id/

Kisworo, R., S.W. Saputra dan A. Ghofar. 2013. Analisis Hasil Tangkapan, Produktivitas, dan Kelayakan Usaha Perikanan Rawai Dasar di PPI Bajomulyo I Kabupaten Pati. Journal of Management Aquatic Resources. Volume 2, Nomor 3, Tahun 2013, Halaman 190-196.

Mulyana, R. 2012. Sistim Pengelolaan Industri Perikanan Tangkap Terpadu Di Wpp Laut Arafura. Disertasi Institut Pertanian Bogor. Tidak Dipublikasikan.

Nikijuluw, V.P.H. 2008. Blue Water Crime: Dimensi Sosial Ekonomi Perikanan llegal. Cidesindo. Jakarta

Pusat Penelitian Pengelolaan Perikanan dan Konservasi Sumber Daya Ikan. 2011. Status dan Perkembangan Perikanan Pukat Udang dan Pukat Ikan. Laporan Hasil Penelitian.

Purwanto, 2013. Status Bio-Ekonomi Perikanan Udang Di Laut Arafura. Jurnal Penelitian Perikanan Indonesia. Vol.19 No. 4 Desember 2013.

Walters, C. and R. Hilborn. 1976. Adaptive Control of Fihing System. J. Fish. Res. Board. Can. 
Wedjatmiko, 2008. Komposisi Jenis, Kepadatan Stok, Aspek Biologi, dan Distribusi Kepiting Di Perairan Arafura. Bawal: Vol.2 No.2-Agustus 2008.

Yamaguchi, H., Y. Goto, N. Hoshino and K. Miyashita. 2014. Growth and Age Composition Of Northern Shrimp Pandalus Eous Estimated By Multiple Length Frequency Analysis. Fisheries Science. 


\section{Appendix 1 . Output OLS Model Walter-Hilborn}

Kapal pancing rawai dasar

\begin{tabular}{|c|c|c|c|c|c|c|}
\hline \multicolumn{2}{|c|}{ Regression Statistics } & & & & & \\
\hline Multiple R & 0,722589515 & & & & & \\
\hline R Square & 0,522135608 & & & & & \\
\hline Adjusted R Square & 0,426562729 & & & & & \\
\hline Standard Error & 0,255310672 & & & & & \\
\hline Observations & 13 & & & & & \\
\hline \multicolumn{7}{|l|}{ ANOVA } \\
\hline & $d f$ & SS & MS & $F$ & Significance $F$ & \\
\hline Regression & 2 & 0,712223 & 0,3561119 & 5,463219 & 0,024918 & \\
\hline Residual & 10 & 0,651835 & 0,0651835 & & & \\
\hline \multirow[t]{2}{*}{ Total } & 12 & 1,364059 & & & & \\
\hline & Coefficients & $\begin{array}{l}\text { Standard } \\
\text { Error }\end{array}$ & $t$ Stat & $P$-value & Lower 95\% & Upper 95\% \\
\hline Intercept & 1,594738 & 0,615484 & 2,5910295 & 0,026902 & 0,223353 & 2,9661241 \\
\hline Ut & $-0,0201881$ & 0,006113 & $-3,3020644$ & 0,007985 & $-0,033810$ & $-0,0065657$ \\
\hline Et & $-0,0001655$ & 0,000169 & $-0,9758769$ & 0,352141 & $-0,000543$ & 0,0002124 \\
\hline
\end{tabular}

Kapal Pukat/trawl

\begin{tabular}{|c|c|c|c|c|c|c|}
\hline \multicolumn{2}{|c|}{ Regression Statistics } & & & & & \\
\hline Multiple R & 0,728995578 & & & & & \\
\hline R Square & 0,531434552 & & & & & \\
\hline Adjusted R Square & 0,437721463 & & & & & \\
\hline Standard Error & 0,261837568 & & & & & \\
\hline Observations & 13 & & & & & \\
\hline \multicolumn{7}{|l|}{ ANOVA } \\
\hline & $d f$ & SS & MS & $F$ & Significance $F$ & \\
\hline Regression & 2 & 0,7775770 & 0,388789 & 5,67086792 & 0,022586623 & \\
\hline Residual & 10 & 0,6855891 & 0,068559 & & & \\
\hline \multirow[t]{2}{*}{ Total } & 12 & 1,4631661 & & & & \\
\hline & Coefficients & $\begin{array}{c}\text { Standard } \\
\text { Error }\end{array}$ & $t$ Stat & $P$-value & Lower 95\% & Upper 95\% \\
\hline Intercept & 1,720052624 & 0,6249401 & 2,752348 & 0,0203959 & 0,3275991 & 3,1125061 \\
\hline Ut & $-0,008676814$ & 0,0025772 & $-3,36664$ & 0,0071618 & $-0,0144193$ & $-0,0029342$ \\
\hline Et & $-0,000455325$ & 0,0004122 & $-1,10462$ & 0,2951936 & $-0,0013737$ & 0,0004631 \\
\hline
\end{tabular}

